УДК 340.12

DOI https://doi.org/10.32849/2663-5313/2020.11.33

\title{
Іван Мотиль,
}

канд. юрид. наук,

директор

Навчально-наукового інституту заочного та дистаниійного навчання

Національної академії внутрішніх справ

\section{ПЕРЕБУДОВА ДЕРЖАВНИХ ОРГАНІВ В УМОВАХ РОЗВИТКУ ПРАВОВОЇ СИСТЕМИ УКРАЇНИ}

У статті розглянуто питання реформування органів правосуддя, органів юстииії та окремих правоохоронних органів в умовах розвитку правової системи України, а також визначено основні пріоритетні шляхи перебудови. 3'ясовано, що загальна тенденція гуманізації права принесе зміни і в організачійну основу суддівської діяльності, що має відобразитись у реалізачій нормативних положень щодо створення суду присяжнх $і$ забезпеченні таким чином приниипів об'єктивності, неупередженості та справедливості. У результаті на індивідуальному рівні мають відбутися переорієнтаиія професійної свідомості судді, психологічне ускладнення проиедури ухвалення рішення. Лише присутність присяжни дасть змогу розділити внутрішне переконання судді на професійне та людське, без створення загрози для нього порушити проиесуальний закон. У иьому ж напрямі гуманізащійних процесів розглядається і перспектива створення ювенальної юстииії, що межує з тендениією спеціалізачії правосуддя. Визначено, що однією зі стійких тендениій судово-правової реформи в Україні є тенденція роздержавлення правових інститутів, які за своєю природою є не державними, а суспільними, що відбилося і на розвитку органів нотаріату. Чому ж нотаріат уважається не державним, а суспільним інститутом? Тому що його завданням є охорона прав $і$ законних інтересів фізичних і юридичних осіб, які не завжди збігаються з інтересами держави. Зроблено висновок, що рух у напрямі до європейських стандартів є не тільки стимулюючим чинником, що ставить низку нових завдань, загострює водночас й деякі застарілі проблеми. Так, у сучасних публікачіях із питань розвитку нотаріату наголошується на необхідності суворого дотримання приниипу рівності права громадян на правову допомогу, а отже, запровадження єдиної системи розиінок на нотаріальні дії. Конкуренція має залежати не від иіноутворення за домовленістю (останнього взагалі не існує), а від правових послуг, знань, сервісу, зокрема й увічливого, шанобливого ставлення до клієнта. Невідкладною є й проблема прозорості процедури встановлення квот, призначення на посаду нотаріусів, що безпосередньо пов'язується з рівним доступом у реалізаиії права на професію.

Ключові слова: реформування, державні органи, правосуддя, юстиція, правова система.

Постановка проблеми. У результаті проведеного аналізу юридичних досліджень присвячених проблематиці практичної діяльності, привертає увагу той факт, що найбільший інтерес науковці та практики виявляють до питань правосуддя, прокурорського нагляду й адвокатської діяльності. Можливо, це можна пояснити тим, що у правовому розвитку України саме ці напрями діяльності 3 найбільшою вірогідністю свідчать про стан демократичного розвитку українського суспільства та проблеми, що склалися на шляху демократизації.

Правосуддя сучасної України - сфера захисту інтересів найрізноманітніших суб'єктів, яка протягом кількох років перебуває у стані перманентного розвитку відповідно до конституційних засад, що далеко не свідчить про відсутність вад у іiї реформуванні. 3 одного боку - величезні сподівання на високий рівень ефективності нової моделі, з іншого - посилення прояву негативних моментів, які спостерігалися до й після реформеного періоду. Склалася чітко виражена тенденція відходу від декларованої на концептуальному рівні мети. Новий Закон «Про судоустрій України» не виконав свою функцію та не виправдав сподівань суспільства і представників самої судової влади. Суди по суті не стали незалежними, неупередженими і справедливими. На цю тему публікується багато статей, звітів керівних установ тощо, але аналітика робиться на рівні публіцистичного матеріалу, не ведуться спеціальні монографічні дослідження. Проте зауважимо, питання проблем або недоліків судової системи є досить висвітленим, не потребує проведення додаткових пошуків. На нашу думку, у цій ситуації спрацював дуже вагомий негатив, що характеризує й інші сторони функціонування правової системи, як-от неузгодженість. По-перше, 
неузгодженість нормативної бази, по-друге, неузгодженість дій представників різних політичних сил та відомств [1]

Метою статті $є$ розгляд питання реформування органів правосуддя, органів юстиції й окремих правоохоронних органів в умовах розвитку правової системи України.

Виклад основного матеріалу. За словами автора одного із законопроєктів В. Шишкіна, Закон України «Про судоустрій України» отримав негативну оцінку ще на етапі його ухвалення. Експерти Ради Свропи вказали не тільки на вади організаційної побудови судової влади. Не відповідають, за їхніми висновками, європейським стандартам непрозора, бюрократична, неконкурсна, неодноразово дубльована численними органами система відбору, призначення й обрання суддів, що створює умови для дії суб'єктивних чинників і корупції. Зокрема, як говорить В. Шишкін, у доборі кадрів і призначенні суддів та голів судів беруть участь голови судів усіх ланок і рівнів, кваліфікаційні комісії суддів. Державна судова адміністрація України, ради суддів усіх рівнів, Вища рада юстиції. Адміністрація Президента України, Президент і Верховна Рада України та їі комітети, а також апарати цих органів, що призводить до того, що процес призначення суддів триває до одного року. Однак не тільки висновки експертів Ради Свропи формують оцінне уявлення щодо судочинства сучасної України. Найбільш вагомим чинником варто визнати аналіз результатів дванадцятирічного реформування судової влади або саме життя у формі юридичної практики судів.

Водночас критичний підхід у висвітленні ситуації, що склалася, дає змогу говорити не тільки про проблеми, а й про перспективи розвитку, вдосконалення судочинства. Цьому питанню також присвячується чимало публікацій, у яких пропонуються приблизно однакові рецепти подолання кризи. Привертає увагу загальна позиція авторів, яку можна назвати критичною або жорстко критичною, особливо якщо висловлюються представники власне судової влади, і водночас прогностичною, що логічно випливає 3 першого. На жаль, зберігається вузькосистемний підхід як бачення представників судової системи, збагачений великим практичним досвідом. Узагалі не проводяться паралелі з іншими соціальними системами, елементами національної правової системи України.

Серед перспектив, що на концептуальному рівні розглядаються як напрями розвитку правосуддя, зазначаються такі, як створення належних матеріально-технічних умов функціонування, забезпечення незалежності, об'єктивності в ухваленні рішень, підвищення рівня професійності, моральності, авторитетності суддівського корпусу, наближення до європейських стандартів у питаннях захисту прав людини та громадянина, які цілком відповідають меті розпочатої у 2002 р. так званої «малої судової реформи». На ії виконання та відповідно до тих тенденцій, що намітилися у правовому житті українського суспільства, пропонуються Концепцією розвитку системи правосуддя на 2004-2014 рр. ужиття низки заходів, що вплинуть на зміст, форми та тенденції розвитку правового виховання у сфері правосуддя. Так, тенденція інтеграції України до світової спільноти впливає на порядок кадрового забезпечення судової системи, підвищення вимог до кандидатів, уведення принципу публічності у призначеннях на посаду, продовження терміну призначення на посаду від 10 років до моменту безстрокового обрання [2, с. 123-124].

В організаційному плані, згідно з тенденцією наближення до європейських стандартів, професію судді очікують подальша спеціалізація, розвантаження, комп'ютеризація і підвищення рівня заробітної плати та посилення соціальних гарантій з одночасним підвищенням вимогливості [3, с. 32-37].

Багато в чому підвищення ефективності суддівської діяльності залежатиме від якісної організації роботи помічників, консультантів, які забезпечують дотримання регламенту діловодства, від інших внутрішньосистемних (відомчі) чинників, які потребують постійного моніторингу. Одна з новацій - це запровадження в судовій системі модельних судів що є концептуальним положенням реформування організаційної діяльності судового органу [4, с. 5].

У ракурсі тенденції євроінтеграції варто розглядати й перспективи вирішення питання про підвищення статусу суддівського самоврядування, яке має стати найважливішою гарантією забезпечення незалежності суддів і судів України. Уведення положень, які стосуються питань суддівського самоврядування, до одного загального закону шляхом припинення дії окремого спеціального закону про ці органи, уважають судді Харківської області, варто розглядати як приниження ролі суддівського самоврядування в житті нашого суспільства та крок назад у питаннях незалежності судової влади. На їхню думку, право на зазначені твердження дають міжнародні стандарти, які вимагають від держави створення для суддів незалежності, ефек- 
тивності в їхній діяльності, що закріплені у Всесвітній хартії суддів. Європейській хартії суддів про статус суддів, які розроблено з урахуванням рекомендацій Кабінету Міністрів Ради Європи «Про незалежність, ефективність і роль суддів» від 13 жовтня 1994 р. [5].

Загальна тенденція гуманізації права принесе зміни й в організаційну основу суддівської діяльності, що має набути відображення в реалізації нормативних положень щодо створення суду присяжних і забезпеченні таким чином принципів об'єктивності, неупередженості та справедливості. Як наслідок, на індивідуальному рівні мають відбутися певна переорієнтація професійної свідомості судді, психологічне ускладнення процедури ухвалення рішення. Лише присутність присяжних дасть змогу розділити внутрішнє переконання судді на професійне та людське, не створювати водночас загрози для нього порушити процесуальний закон. $\mathrm{y}$ цьому ж напрямі гуманізаційних процесів розглядається й перспектива створення ювенальної юстиції, що межує з тенденцією спеціалізації правосуддя. Передбачається формування особливого корпусу суддів та судових установ, що будуть орієнтовані на дуже специфічну категорію суб'єктів судового процесу, які належать до поняття «генофонд країни» [6, с. 90-92].

3 ефективністю судової діяльності тісно пов’язується діяльність слідчих підрозділів та інституту державних виконавців, які, 3 одного боку, готують усі матеріали до судового розгляду, а з іншого - забезпечують реальність ухваленого судовою інстанцією рішення. Проте слідча і виконавча робота в умовах правової реформи разом із судовою діяльністю зазнають певних змін, зумовлених як власне процесами планового реформування, так і змінами загального рівня, що спостерігаються на всіх щаблях побудови правової системи [7, с. 3].

Реформування досудового слідства одна 3 актуальних проблем удосконалення судового процесу. Нова модель кримінального судочинства повинна створювати надійні механізми, здатні «убезпечити особу від репресій, безпідставного втручання в її особисте життя, застосування щодо неї заходів кримінально-процесуального примусу» [8]. А це, у свою чергу, вимагає створення нової моделі інституту досудового слідства. Хоч сумно це визнавати, але, незважаючи на зміни, які відбулися у ХХ ст. у підходах до розслідування в Україні кримінальних справ, найважливіший принциповий недолік досудового слідства залишився незмінним - це інквізиційне начало, яке пронизує всю стадію процесу і суперечить засаді змагальності сторін. Інквізиційний характер досудового слідства виявляється насамперед у потрійній ролі, яка законом закріплена за слідчим, а також у суміщенні дізнання (зокрема, розшуку), його мети і засобів із досудовим слідством, його завданнями й можливостями [9, с. 2-5].

Натепер причинами низької ефективності роботи слідчих підрозділів названо перевантаженість слідчих, відсутність належних умов для роботи, непрофесійність та плинність кадрів, існування «телефонного права», неузгодженість чинного законодавства тощо. Одна з головних тем, що викликає занепокоєння вчених, - це забезпечення незалежності та самостійності слідчого [10], відокремлення дізнання.

На думку Б. Романюка, вирішення питання реальної процесуальної незалежності й самостійності слідчого є основою для побудови демократичних засад функціонування слідчого апарату, що зазвичай сприятиме зміцненню справедливості й гуманізації правосуддя. У результаті дослідження цього питання автор дійшов висновку щодо перспектив слідчої діяльності. У функціональному аспекті - це зміцнення принципу змагальності й послаблення інквізиційних начал на стадії досудового слідства. В організаційному - структурна перебудова й перепідпорядкування відомчих слідчих апаратів керівникам, які не очолюють водночас служби дізнання [11, с. 12-15].

Такий підхід, на нашу думку, є поміркованим, розрахованим на поступове реформування та вдосконалення, а також таким, що не призведе до зупинення роботи слідства, хоч і на певний час, як передбачається в разі проведення глобальних реорганізацій.

Але сумнівною є думка щодо розширення суб'єктів здійснення слідчої діяльності, особливо якщо уявити функціонування слідчих підрозділів у складі міністерств, відомств, державних комітетів, які будуть використовуватись як засоби для забезпечення відомчих інтересів.

У руслі загальних тенденцій гуманізації, зміцнення нормативної основи, посилення правових гарантій тощо, які можна спостерігати в окремих ланках правової системи, висвітлюються й процеси розвитку такої важливої інституції, як державна виконавча служба. Характерною рисою є те, що 3 кожним роком свого існування, починаючи з моменту створення у травні 1998 р., виконавча служба набувала все більшого авторитету серед різних верств населення, зміцнювала таким чином авторитет судової влади та наповнювала бюджет держави. 
Зупинимося для прикладу лише на одному з аспектів зазначеної проблематики. У результаті проведеного аналізу статистичних даних Міністерства юстиції України доходимо висновку, що навантаження на службу загалом за період 2006-2011рр. збільшилося в кілька разів - від 1366340 виконаних документів до 5285 157. Оптимальне навантаження на одного державного виконавця на місяць, згідно з наявними розрахунками, становить 40-50 виконавчих документів. Проте протягом усього періоду існування служби навантаження на кожного державного виконавця перевищувало нормативи як мінімум удвічі: 2006 р. - 85 на одного виконавця; 2007 р. -92 ; 2008 р. - 112; 2009 р. 149; 2010 р. - 100; 2011 р. - 107 документів [12, c. 129-135].

Якщо водночас взяти до уваги особливості розташування об'єктів у сільській місцевості, відсутність транспорту, зв’язку, оперативність і винахідливість окремих боржників, то можна лише уявити якість та своєчасність виконання рішень.

Водночас вивчення й аналіз проблематики в роботі підрозділів виконавчої служби дали змогу визначити низку основних напрямів розвитку служби на перспективу.

Одним із першочергових заходів планується посилення правового захисту державних виконавців від різного роду форм перешкоджання їхній діяльності, а також від посягань на життя, здоров'я, житло й майно зазначених осіб та їхніх близьких родичів у зв'язку зі службовою діяльністю цих працівників.

Для посилення контрольних функцій виконавців, здешевлення окремих стадій провадження планується розширити повноваження державних виконавців у питаннях реалізації арештованого майна. Щодо зовнішнього контролю за роботою виконавчих установ, то пропонується унеможливити розгляд скарг зацікавленою особою, передати це право виключно суду.

Загальна тенденція та життєва необхідність посилення гарантій юридичної роботи зумовили появу концептуального рішення щодо силового забезпечення процесу виконавчого провадження (вилучення, виїмка майна, здійснення розшуку боржника, дитини, майна боржника).

Нові вимоги щодо ефективності юридичної роботи вимагають вдосконалення низки організаційних питань, особливо в напрямі узгодженості, взаємодії з іншими інституціями, насамперед органами правосуддя. Із цією метою пропонується реорганізувати Департамент державної виконавчої служби шляхом створення урядового органу, який би об'єднав органи державної виконавчої служби й органи Судової адміністрації України.

Цікавою, але досить спірною виглядає поки що ідея щодо створення інституту приватних виконавців, хоч і з диференційованим підходом до їхніх повноважень та категорії документів, що мають ними виконуватись. Виконавча діяльність повинна бути провадженням процедури судового захисту, а суд має діяти тільки від імені держави. Крім того, натепер дуже важко уявити дотримання правових стандартів приватними об'єднаннями під час виконання примусових дій, якщо за цим стоїть матеріальний інтерес.

Явною прогалиною в концепції $є$ відсутність такого напряму роботи, як кадрове забезпечення. 3 огляду на відсутність спеціального навчального закладу, який би готував державних виконавців, інституту підвищення кваліфікації, а також незначний термін існування державної виконавчої служби, відсутність належної кількості високодосвідчених кадрів такий напрям у концепції має бути.

Крім того, якщо передбачити реалізацію ініціатив стосовно приватного виконавчого провадження, то, зважаючи на досвід нотаріату, можна передбачити, що частина вже досвідчених кадрів виконавчої служби перейдуть 3 державного до приватного сектора, кадрова проблема стане ще гострішою.

Нотаріальна діяльність є окремим напрямом або сферою юридичної роботи, у межах якої також відбуваються зміни, спостерігаються тенденції, які свідчать про прогресивний розвиток нотаріату, а також про невичерпні потенційні можливості його вдосконалення.

Однією зі стійких тенденцій судово-правової реформи в Україні є тенденція роздержавлення правових інститутів, які за своєю природою є не державними, а суспільними, що відбилося і на розвитку органів нотаріату. Чому ж нотаріат вважається не державним, а суспільним інститутом? Тому що його завданням є охорона прав і законних інтересів фізичних і юридичних осіб, які не завжди збігаються з інтересами держави. На жаль, в Україні дотепер поняття «публічний» ототожнюється 3 поняттям «державний», отже, ототожнюються держава і суспільство, державні інтереси із суспільними. Проте, на думку В. Черниша, нотаріальна система може бути вільною або публічною (державною) [13]. Хоча насправді держава це похідний від суспільства інститут.

Як приклад наведемо деякі статистичні дані, що характеризують стан роботи у приватному нотаріальному секторі. Так, у 2008 p. 
в Україні налічувалася 801 державна нотаріальна контора, у яких працювали 1332 державних нотаріусів та 484 консультантів. Приватних нотаріусів зареєстровано 2 598, що більше, ніж у державному секторі майже удвічі. Проте загрози в цьому ніякої немає. Крім того, ця тенденція продовжує мати місце. Від приватних нотаріусів, які здійснюють свою діяльність за принципом самофінансування, у 2008 р. до державного бюджету надійшло понад 61 млн грн, а до Пенсійного фонду ними перераховано 23,8 млн грн [14, с. 171].

Можна було б наводити й інші цифри, але доцільно зупинитися на перспективах розвитку цієї інституції, виходячи з перспектив правового розвитку українського суспільства та його правової системи. Натепер щодо цього фахівці вказують на необхідність вирішення таких проблем, як забезпечення незалежності нотаріуса, позбавлення нотаріату невластивих йому функцій, забезпечення внутрішнього надійного й ефективного контролю за роботою нотаріусів. Окремо наголошується на необхідності введення спрощеного оподаткування. Як зауважив на Всеукраїнській конференції нотаріусів у 2009 р. Президент Української нотаріальної палати В. Черниш, потребують більш глибокого розроблення питання філософії, логіки, праксеології нотаріату. Та найбільш гостро стоїть нині на порядку денному питання деонтології нотаріату.

\section{Висновки}

Така перспектива, як рух у напрямі до європейських стандартів, $є$ не тільки стимулюючим чинником, що ставить низку нових завдань, а загострює водночас і деякі застарілі проблеми. Так, у сучасних публікаціях із питань розвитку нотаріату наголошується на необхідності суворого дотримання принципу рівності права громадян на правову допомогу, а отже, запровадження єдиної системи розцінок на нотаріальні дії. Конкуренція має залежати не від ціноутворення за домовленістю (останнього взагалі не існує), а від правових послуг, знань, сервісу, зокрема й увічливого, шанобливого ставлення до клі- єнта. Невідкладною є й проблема прозорості процедури встановлення квот, призначення на посаду нотаріусів, що безпосередньо пов'язується з рівним доступом у реалізації права на професію.

\section{Список використаних джерел:}

1. Про судоустрій : Закон України від 7 лютого 2002 р. № 3018-III.

2. Оверчук С. Розбудова ювенальної юстиції в Україні - потреба часу. Юридичний журнал. 2005. № 4. C. 123-124.

3. Грицаєнко Л. Деякі аспекти судово-правової реформи в Україні: реальність та перспективи. Право України. 2004. № 5. С. 32-37.

4. Маляренко В. Суддя - визначальний фактор існування демократичного суспільства. Вісник Верховного Суду України. 2003. № 6. С. 5.

5. Бородін М., Лустиник Д. Роль і значення органів суддівського самоврядування у становленні незалежної судової влади в Україні. Право Украйни. 2005. № 3. С. 19-22.

6. Козлов Д. Судді права і судді факту. Або дещо про суд присяжних та можливості запровадження цього інституту в Україні. Юридичний журнал. 2005. № 3. С. 90-92.

7. Стретович В. Правова система України: загальна характеристика сучасного етапу формування. Право України. 1998. № 2. С. 3-6.

8. Трофименко В. Забезпечення прав підсудного на захист. Проблемні питання. Прокуратура, людина, держава. 2010. № 2. С. 73-74.

9. Маляренко В. Про досудове слідство, його недоліки і реформування. Вісник Верховного Суду Украӥни. 2004. № 8. С. 2-5.

10. Теорія держави і права. Академічний курс : підручник / О. Зайчук та ін. ; М-во освіти і науки України. Київ : Юрінком-Інтер, 2006 р. 685 с.

11. Романюк Б. Проблеми перебудови досудового слідства. Адвокат. 2005. № 1. С. 12-15.

12. Семерга С., Шупєня М. Оцінка роботи державної виконавчої служби через призму статистичних показників. Бюлетень Міністерства юстииї̈ Украӥни. 2012. № 1. С. 129-135.

13. Черниш В. Цивільно-правові засади розвитку нотаріату в Україні : автореф. дис. ... канд. юрид. наук. Київ, 2003. 22 с.

14. Єфіменко Л. До питання щодо діяльності нотаріату, реєстрації актів цивільного стану громадян та громадських об'єднань. Бюлетень Міністерства юстииї України. 2009. № № 2-3. C. 170-179.

Ivan Motyl. Restructuring of the government authorities in the context of the development of the legal system of Ukraine

The article deals with the reform of justice, justice, and individual law enforcement agencies in developing the legal system of Ukraine and the main practical aspects of adjustment. It was found that the general trend of humanization of law will bring changes in the organizational basis of judicial activity, which should be reflected in the implementation of regulations on the establishment of a jury trial and thus ensure the principles of objectivity, impartiality and fairness. As a result, at the individual level there should be a certain reorientation of the professional consciousness of the judge, a psychological complication of the decision-making procedure. Only the presence of a jury will allow to divide the inner conviction of a judge into professional and human, 
without creating a threat for him to violate the procedural law. In the same direction of humanization processes the prospect of creation of juvenile justice which borders on a tendency of specialization of justice is considered also. It is determined that one of the stable tendencies of judicial and legal reform in Ukraine is the tendency of privatization of legal institutions, which by their nature are not state, but public, which affected the development of notarial bodies. Why is a notary not considered a state but a public institution? Because its task is to protect the rights and legitimate interests of individuals and legal entities, which do not always coincide with the interests of the state. It is concluded that the movement towards European standards is not only a stimulating factor that poses a number of new challenges, while exacerbating some outdated problems. Thus, modern publications on the development of notaries emphasize the need for strict adherence to the principle of equal rights of citizens to legal aid, and hence the introduction of a single system of prices for notarial acts. Competition should not depend on pricing by agreement (the latter does not exist at all), but on legal services, knowledge, service, including polite, respectful attitude to the client. There is also an urgent problem of transparency in the quota setting procedure, appointment of notaries, which is directly related to equal access to the right to a profession.

Key words: reform, public authorities, justice, justice, legal system. 